\title{
Sociobiology
}

RESEARCH ARTICLE - WASPS

\section{The Effect of Forest Fragmentation on Polistinae}

\author{
ET Bueno', MM SOUZA', MA Clemente² \\ 1 - Instituto Federal de Ciência e Tecnologia- Sul de Minas Gerais, Inconfidentes-MG, Brazil \\ 2 - Universidade Estadual Paulista "Júlio de Mesquita Filho", Instituto de Biociências, Zoology Department, Rio Claro-SP, Brazil
}

\section{Article History \\ Edited by \\ Evandro N. Silva, UEFS, Brazil \\ Received 22 February 2019 \\ Initial acceptance 29 May 2019 \\ Final acceptance 29 May 2019 \\ Publication date 14 November 2019}

\section{Keywords}

Atlantic Rainforest; Vespidae; Epiponini; Pseudopolybia; Mischocyttarus.

\section{Corresponding author}

Marcos M. Souza

Instituto Federal de Ciência e

Tecnologia- Sul de Minas Gerais

Campus Inconfidentes

Praça Tiradentes, n416, Centro

CEP. 37576-000 - Inconfidentes-MG, Brasil.

E-Mail:marcos.souza@ifsuldeminas.edu.br

\begin{abstract}
The forest fragmentation is caused by natural or anthropic actions, which affect negatively the biota and the environmental services rendered by biological diversity. However, there is little information on the reflex of these actions in many different groups of animals, such as social wasps, which are abundant and significantly present in neotropical environments, causing a major impact in the communities they live due to their role in food webs. As their natural enemies, wasps are important in the control of agricultural plagues; in the natural environment, they are nectar collectors, frequent flower visitors, and potential pollinators of many species of plants. These factors justify studies which would evaluate in what way the forest fragmentation acts on these insects biodiversity. This study was carried out in four fragments, each of a different size, located in the municipalities of Inconfidentes and Ouro Fino, in the south of the state of Minas Gerais (Brazil), where the phytophysiognomy is the Montane Semideciduous Seasonal Forest. The research was carried out between December 2016 and March 2018, with the same sampling collection for each fragment, totalizing 104 sampling days. In total, 28 species and 51 colonies were recorded in the four areas and a greater richness for the greatest fragment (F4). The conclusion reached was that the size and heterogeneity of the fragment have an important role in maintaining the richness of social wasps.
\end{abstract}

\section{Introduction}

A forest fragment is defined as a natural vegetation area interrupted by natural or anthropic barriers (e.g., roads, villages, agricultural and forestal crops, pastures, mountains, lakes, dams) which are capable of significantly diminishing the flow of animals, floral resources, pollen and seeds (Viana \& Tabanez, 1996), altering the biota (Laurence et al., 2006; Nascimento et al., 2006) and the habitat abiotic factors - and, consequently, the nesting places of social insects (Schwarcz Filho et al., 2004). This fragmentation process negatively affects different ecosystems, especially the Atlantic Rainforest, which has been suffering for thousands of years (Dean, 1997).

The Atlantic Rainforest, with its varied phyto physiognomies, is Brazil's oldest forest formation, having been established at least 70.000 .000 years ago, in a practically continuous coverage along the coastal region. It extends from the Northeast region until the state of Rio Grande do Sul; its central portion is located in the Sea Mountain and Mantiqueira Mountain, comprising the states of São Paulo, Minas Gerais, Rio de Janeiro and Espírito Santo (Rizzini, 1997). This biome contains an abundance of ecosystems regarding biological diversities (Myers et al., 2000), however, the vast majority of its reminiscent is in small fragments (Viana \& Tabanez, 1996).

In these fragments, the plant populations are comprised of few individuals of the same species, which generates a considerable percentage of endogamy and consequently a high probability of extinction of the local species (Costa, 2003). However, these few reminiscents may work as stepping stones (linking points or ecological trampolines), which are small habiting areas scattered through the array which may help some species in the flow between fragments, since there is 
the occurrence of ecological corridors to allow these actions, which also reflects upon the fauna (Viana \& Pinheiro, 1998).

It is vital to understand how the animal populations behave when confronted with environmental fragmentation in order to establish actions that can minimize the negative effects of this process on the biota; however, there is little to no information on a variety of animals in this context, such as wasps, both the solitary (Morato \& Campos, 2000) and the social ones (Graça \& Somavilla, 2018).

These insects are commonly known in Brazil as marimbondos or cabas, and belong to the Hymenoptera order, Vespidae family, which is comprised of six subfamilies grouping solitary species (Massarinae, Eumeninae, and Euparigiinae) and social species (Stenogastrinae, Vespinae, and Polistinae) (Carpenter \& Marques, 2001).

There are, around the globe, 974 species of social wasps, from which 552 occur in the American continent and 346 in Brazil (Carpenter \& Anderna, 2013), where there is only the recording of the subfamily Polistinae, with 26 described genera (Carpenter \& Marques, 2001).

They perform many environmental services in different natural and agricultural ecosystems, acting in the biological control as predators of many insects which are plagues in different cultures (Carpenter \& Marques, 2001; Prezoto et al., 2005; Hunt, 2007; Souza \& Zanuncio, 2012); they are potential pollinators of different species of angiosperms (Clemente et al., 2012), constitute important floral visitors (Santos et al., 2006; Clemente et al., 2012), and can be used as bioindicators of the conservation level of the riparian forest (Souza et al., 2010).

Studies that utilized the social wasps as ecological models to evaluate the impact of fragmentation are scarce, however, Graça and Somavilla (2018) have made an important contribution to the Amazon Biome, showing that the continuous vegetation areas are home to an abundance (common and rare), richness and diversity greater than when compared to the fragments highly affected by anthropic actions.

Considering the factors of abundance, richness, diversity, registration ease, colony monitoring, and constancy in the different seasons of the year, the social wasps show themselves as an interesting group to be evaluated regarding the forest fragmentation effects. Therefore, it is expected that the largest forest fragments house a greater richness of social wasps, as well as a higher number of colonies.

\section{Material and Methods}

The study was performed from December 2016 to March 2018 in four forest fragments, each one with a different size (Fig. 1, Table 1) in the municipalities of Inconfidentes (Fragment F1, Fragment F2, and Fragment F3) and Ouro Fino (Fragment F4), in the south of the state of Minas Gerais, Brazil. For each area, 26 days of sampling were carried out, which adds up to 104 days of sample collection, in a total of 2096 hours of sampling.

The areas have similar ecological characteristics (as shown in Table 1) but differ in size, circularity and surrounding array.

The researched areas are Montane Seasonal Semideciduous Forest, in the domain of the Atlantic Rainforest Biome (Oliveira Filho, 2006). To record the species two methodologies were applied: the active search and the attractive traps. The first was used between 8 a.m. and 5 p.m. in the four seasons of the year, split in five days for each forest fragment in a total of 80 hours of sampling, performed by three researchers. This method was consisted of running across the pre-existant tracks in the border and interior of the forest, and the capturing of the insects was assisted by an entomological web.

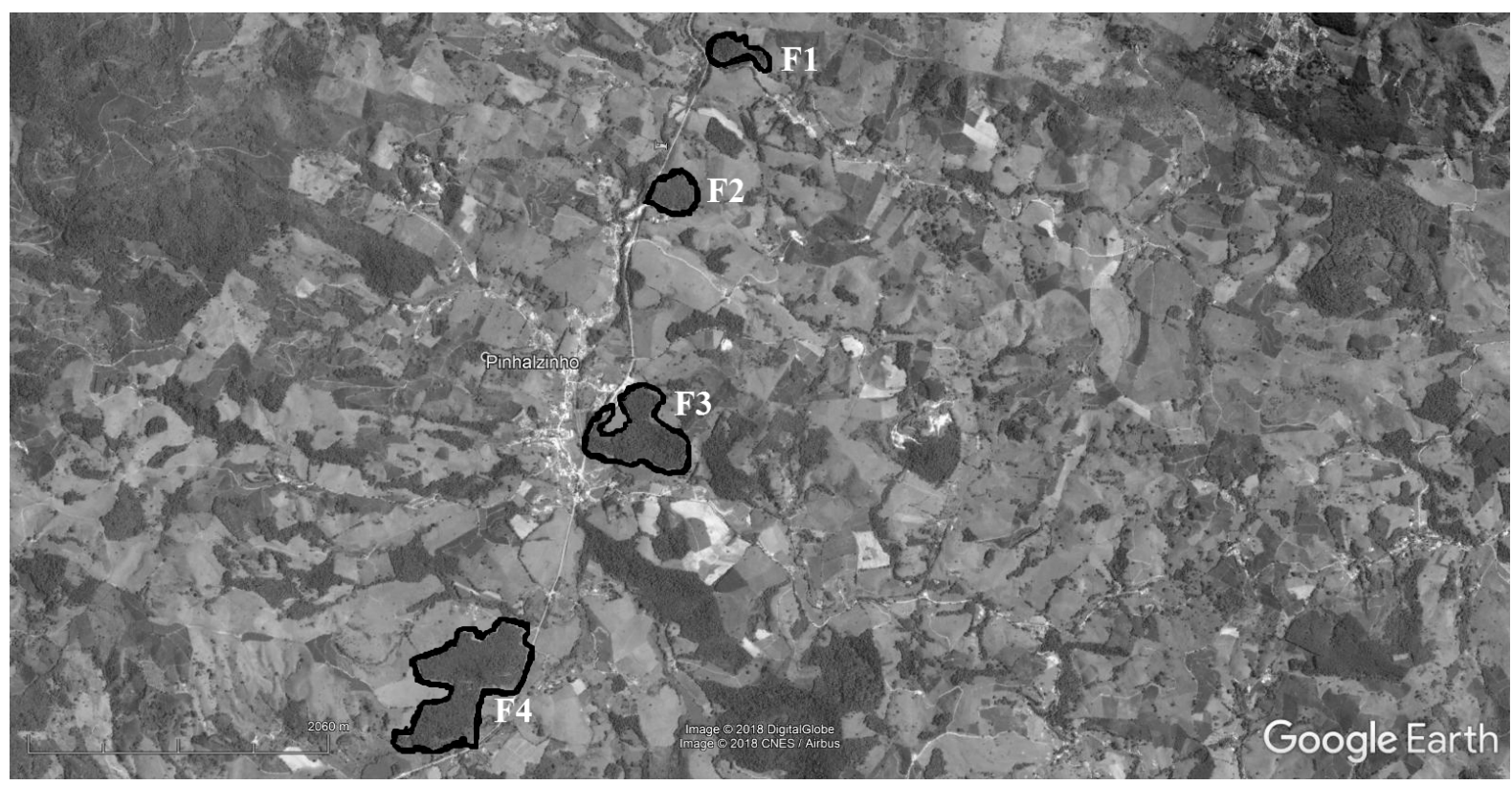

Fig 1. Location of the Montane Semideciduous Seasonal Forest fragments used to evaluate the impact of fragmentation on the social wasps' communities in the south side of the state of Minas Gerais, in the Southeast region of Brazil. 
The second methodology, the attractive traps, was used with PET bottles, as suggested by Souza et al. (2015a). Ten unities were distributed for each fragment in three months September and October 2017, and March 2018 - being kept in the field for seven consecutive days, in a total of 84 sampling days, being 21 for each fragment. The traps were distributed in sites indicated by the researcher, considering the highest possibility if collecting social wasps, such as forest border, close to water courses etc. The bottle-traps were placed in a straight line and hang in the vegetation at 1,5 meters from the ground, with a distance of 10 meters between them and utilizing as bait $250 \mathrm{~mL}$ of fresh passionfruit juice (Souza et al., 2015a). At the end of the seventh day after the installation of the traps on the field, the material was sorted with a clamp and a sieve and subsequently accommodated in 70\%-pure alcohol, in order to be possible to proceed with the assembling and identification.

The species were stored in wet and dry methods in the biological collection of the Federal Institute of the South of Minas Gerais (IFSULDEMINAS), in the Incondidentes campus, and registered on the website of the Reference Center for Environmental Information (CRIA). The identifications were performed with the help of taxonomic keys (Carpenter \& Marques, 2001), and by comparison with the samples of the aforementioned biological collection performed by Professor Orlando Tobias da Silveira, Ph.D., from the Emílio Goeldi Museum (in Belém, Pará).

In order to analyze the diversity, the researchers considered the number of colonies for each species (Souza et al., 2010), adopting the Shannon-Weaver index; to evaluate the fauna similarities between the fragments, a grouping analysis was performed via the Unweighted Pair-Group Method using Arithmetic Means (UPG-MA), through the Jaccard similarity coefficient (Krebs, 1998).

\section{Results and Discussion}

A total of 28 species and 21 colonies was registered, being the fragment $\mathrm{F} 4$ the one which presented greater richness, with 21 species (Table 2), seven of them being exclusive (Mischocyttarus atrametarius, Mischocyttarus cassununga, Mischocyttarus sp. 2, Mischocyttarus wagneri, Polybia minarum, Polybia platycephala, Pseudopolybia vespisceps); nevertheless, it presented a lower diversity level than F1.

The fragment $\mathrm{F} 4$ has $336,367 \mathrm{~m}^{2}$, being the largest area in the study; it also has hydric resources, and there is no agricultural activity or eucalyptus plantation in its array. These characteristics have a positive implication in the richness of wasps sampled (21 species), since they allow the establishment and survival of more species of social wasps, creating distinct microhabitats for the organisms and therefore providing more protection of predators and increasing the availability and diversity of food resources and nesting substrates (Santos et al., 2007; Francisco et al., 2018).

Another important factor is the size of the fragment F4, which is from 15 to $58 \%$ larger than the other areas (Table 1), added to the heterogeneity of the environment, which is in intermediate regeneration, as discussed by some authors (Morato \& Campos, 2000; Santos et al., 2007). This fragment was also the only one in which the species Pseudopolybia vespiceps was registered. It is considered a bioindicator of well-conserved riparian forest continuous areas (Souza et al., 2010); its less significant ecological plasticity entails a restriction of environments with specific conditions, transforming the species in a specialist in specific habitats (Cruz et al., 2006), which sustains the hypothesis of why the fragment F4 presents more richness.

Table 1. Different ecological characteristics regarding size and pastoral agricultural activities in the forest fragments (F1, F2, F3, and F4) in which the social wasps' communities were evaluated, in the south of the state of Minas Gerais, in the Southeast region of Brazil.

\begin{tabular}{|c|c|c|c|c|}
\hline Fragment characteristics & Fragment F1 & Fragment F2 & Fragment F3 & Fragment F4 \\
\hline Coordinates & $\begin{array}{l}22^{\circ} 23^{\prime} 60^{\prime \prime} \mathrm{S}, \\
46^{\circ} 20^{\prime} 26^{\prime \prime} \mathrm{W}\end{array}$ & $\begin{array}{l}22^{\circ} 22^{\prime} 21^{\prime \prime} \mathrm{S}, \\
46^{\circ} 19^{\prime} 34^{\prime \prime} \mathrm{W}\end{array}$ & $\begin{array}{l}22^{\circ} 21^{\prime} 93 " \mathrm{~S}, \\
46^{\circ} 20^{\prime} 55^{\prime \prime} \mathrm{W}\end{array}$ & $\begin{array}{l}22^{\circ} 20^{\prime}, 74^{\prime \prime} \mathrm{S}, \\
46^{\circ} 20^{\prime} 95^{\prime \prime} \mathrm{W}\end{array}$ \\
\hline Circularity index & 0,52 (highly elongated) & 0,93 (rounded) & 0,6 (elongated) & 0,6 (elongated) \\
\hline $\begin{array}{l}\text { Presence of lentic and } \\
\text { lotic water courses }\end{array}$ & + & + & + & + \\
\hline Agricultural activity & - & - & + & - \\
\hline Eucalyptus cultivation & + & - & - & - \\
\hline Canopy formation & + & + & + & + \\
\hline
\end{tabular}

Presence (+) and absence (-) 
In the samples performed with the attractive traps, both Agelaia multipicta and A. pallipes were registered in all the fragments. It is notable the abundance of A. pallipes (65 individuals) in the fragment F1, probably due to the smaller size of the fragment, increasing the probability of the trap being installed close to a colony, combined with the fact that the size of the area makes the foraging easier, since the range of action of the social wasps is on average 200 meters (Gomes et al., 2007; Bichara Filho et al., 2009).

In larger areas, the competition among the species from close taxons which explore the same resources tends to decrease and establish a similar population size (Fox \& Fox, 2000). This behavior is verified in the fragment $\mathrm{F} 4$, where other three species were registered $-A$. multipicta, A. pallipes e A. vicina -, all in similar abundance, which is likely to show the decrease in the competition between the species of this genus. Since it presents a larger area, the fragment F4 has a larger availability of hydric and food resources, in addition to a larger number of nesting sites. The abundance of species from the genus Agelaia in diversity studies is a side effect of a large number of individuals in these colonies (Hunt et al., 2001; Graça \& Somavilla, 2018), as noted in other studies carried out in the state of Minas Gerais (Souza et al., 2012; Souza et al., 2015b).

Nevertheless, when the number of colonies (Table 2) and Shannon-Weaver diversity index are considered - F1 $(2,22003)$, F2 $(1,69574), F 3(1,84622)$ and F4 $(1,95545)$, as calculated based on the number of colonies per species - fragment F1 was more relevant than F4, which may be an outcome of the fact that denser and higher vegetation areas hinder the registration of social wasps' nests (Silveira, 2002; Souza \& Prezoto, 2006) due to the colonies being more cryptic (Wenzel \& Carpenter, 1994), while smaller areas such as F1 experiment the opposite (Souza \& Prezoto, 2006). This situation corroborates the study carried out by Santos et al. (2009) which demonstrated that the abundance of species is not related to the number of nests found in each area.

Considering that the fragments are similar regarding their ecological characteristics but different in size, the method

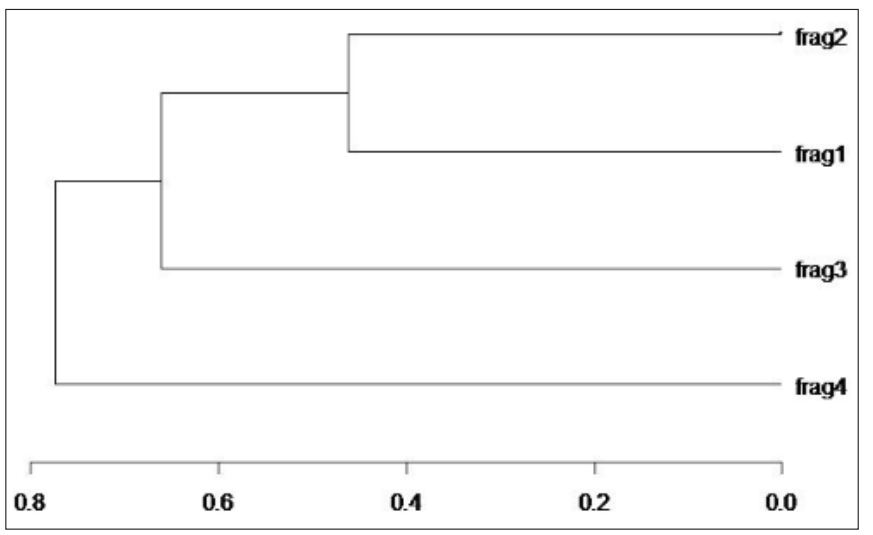

Fig 2. Index of similarity in the social wasps' fauna in the four forest fragments in the municipalities of Inconfidentes and Ouro Fino, in the south of the state of Minas Gerais in the Southeast region of Brazil. of average association was applied to evaluate the similarity of the social wasps' fauna (Fig 2). It was observed that F1 is very similar to F2, including their sizes (Table 1), but they are different from F4, which behaved in a different way, resulting in seven exclusive species - even if F4 is more isolated from the other fragments regarding the other study areas, what can be explained due to the ability of the wasps to adapt to fragmentation better than bees (Morato \& Campos, 2000). Notithstanding, according to Graça and Somavilla (2018) in their study in the Amazon rainforest, it was verified that many species have colonized not only continuous forest areas but also fragments; there is however a decrease in the number and abundance of species, which reveals a rupture in the structure of the fragmented community. Thus, the researchers concluded that the forest fragmentation is likely to threaten abundant and rare species equally.

Five species were collected in all the four fragments (A. multipicta, A. pallipes, A. vicina, Polistes versicolor, and Polybia fastidiosuscula) and other three were common ground to at least three fragments (Mischocyttarus drewseni, Polistes cinerascens, Polistes simillimus, Polybia paulista, and Synoeca cyanea). This suggests that these fragments once formed a continuous forest, and due to its fragmentation the entomofauna of some areas suffered more pressure and lost some species over the time. This is a consequence of the border effect (Lovejoy et al., 1986), which alters the abiotic and biotic factors (Lovejoy et al., 1986; Wirth et al., 2007); as a result, many species are lost (Woodroffe \& Ginsberg, 1998). In the study carried out by Graça and Somavilla (2018) many species were found in both forests, with an emphasis on Agelaia fulvofasciata, Agelaia testacea, Agelaia pallipes, and Polybia rejecta, genera also present in this study. The authors point out that even if the species are present both in the continuous and in the fragmented forest, there was a significant change in the absolute abundance values. These patterns show the fragility of the abundant and the common species, such as the genus Agelaia, which is impacted by anthropic disturbances, being frequently suppressed (Gaston, 2010).

The smaller the fragment, the more severe the border effects manifest themselves, altering the microclimate on forest borders, which increases the probability of species invasion, eventually favoring opportunistic species with specialized habitat (Devictor et al., 2008; Nordén et al., 2013; Matthews et al., 2014), thus limiting its pecial occurrence. Another effect entailed by the fragment isolation is that many species are not able to percolate, hindering the chances of colonization (Tischendorf \& Fahrig, 2000; Blandón et al., 2016).

Under that perspective, the size of the fragment, as well as heterogeneity, seem relevant for the maintenance of the abundance of social wasps, as previously discussed by other authors (Souza et al., 2010; Souza et al., 2014).

The conclusion the present study reaches is that the size of the fragment is a decisive factor concerning the richness, diversity, and abundance of social wasps. These insects may 
Table 2. Species of social wasps (presence +; absence -), number of colonies and number of samples collected by species with a passionfruit attractive trap in four fragments of Montane Semideciduous Seasonal Forest (Frag.) in the municipalities of Inconfidentes and Ouro Fino, in the south of the state of Minas Gerais in the Souutheast region of Brazil.

\begin{tabular}{|c|c|c|c|c|}
\hline Species & Frag. 01 & Frag. 02 & Frag. 03 & Frag. 04 \\
\hline Agelaia pallipes (Olivier, 1791) & $+/ 01 / 65$ & $+/ 00 / 15$ & $+/ 03 / 20$ & $+/ 00 / 12$ \\
\hline Apoica gelida Van der Vecht, 1973 & $-/ 00 / 00$ & $+/ 00 / 02$ & $-/ 00 / 00$ & $+/ 00 / 01$ \\
\hline Mischocyttarus socialis (Saussure, 1854) & $-/ 00 / 00$ & $-/ 00 / 00$ & $-/ 00 / 00$ & $+/ 04 / 00$ \\
\hline Mischocyttarus cerberus styx (Richards, 1940) & $-/ 00 / 00$ & $+/ 01 / 00$ & $+/ 01 / 00$ & $-/ 00 / 00$ \\
\hline Mischocyttarus drewseni Saussure, 1857 & $+/ 02 / 00$ & $+/ 02 / 02$ & $-/ 00 / 00$ & $+/ 02 / 00$ \\
\hline Mischocyttarus mirificus Zikán, 1935 & $-/ 00 / 00$ & $-/ 00 / 00$ & $+/ 01 / 00$ & $-/ 00 / 00$ \\
\hline Mischocyttarus wygodzinskyi Zikán, 1978 & $+/ 02 / 00$ & $-/ 00 / 00$ & $-/ 00 / 00$ & $-/ 00 / 00$ \\
\hline Polistes actaeon Haliday, 1836 & $+/ 01 / 00$ & $-/ 00 / 00$ & $-/ 00 / 00$ & $+/ 00 / 00$ \\
\hline Polistes cinerascens Saussure, 1854 & $+/ 01 / 00$ & $+/ 00 / 00$ & $-/ 00 / 00$ & $+/ 01 / 00$ \\
\hline Polistes simillimus Zikán, 1951 & $+/ 02 / 01$ & $+/ 01 / 00$ & $-/ 00 / 00$ & $+/ 00 / 00$ \\
\hline Polistes versicolor versicolor (Olivier, 1791) & $+/ 01 / 02$ & $+/ 03 / 05$ & $+/ 02 / 00$ & $+/ 00 / 02$ \\
\hline Polybia fastidiosuscula Saussure, 1854 & $+/ 01 / 00$ & $+/ 01 / 05$ & $+/ 02 / 01$ & $+/ 01 / 02$ \\
\hline Polybia ignobilis (Haliday, 1836) & $-/ 00 / 00$ & $-/ 00 / 00$ & $+/ 00 / 00$ & $+/ 01 / 01$ \\
\hline Polybia jurinei Saussure, 1854 & $-/ 00 / 00$ & $+/ 00 / 05$ & $-/ 00 / 00$ & $+/ 00 / 07$ \\
\hline Polybia minarum Ducke, 1906 & $-/ 00 / 00$ & $-/ 00 / 00$ & $-/ 00 / 00$ & $+/ 00 / 01$ \\
\hline Polybia occidentalis occidentalis (Olivier, 1791) & $-/ 00 / 00$ & $-/ 00 / 00$ & $+/ 01 / 00$ & $-/ 00 / 00$ \\
\hline Total & $14 / 16 / 71$ & $12 / 11 / 57$ & $10 / 10 / 41$ & $21 / 14 / 69$ \\
\hline
\end{tabular}

be used as ecological models to forecast the level of impact of fragmentation and vegetation area in resident communities. It is also noted the importance of the preservation of the existing areas and the incentive to increase the vegetation areas.

\section{References}

Bichara-Filho, C.C., Santos, G.M.M., Resende, J.J., Cruz, J.D., Gobbi, N. and Machado, V.L.L. (2009). Foraging behavior of the swarm-founding wasp, Polybia (Trichothorax) sericea (Hymenoptera, Vespidae): prey capture and load capacity. Sociobiology, 53(1): 61-69.

Blandón, A.C., Perelman, S.B., Ramírez, M., López, A., Javier, O. and Robbins, C.S. (2016). Temporal Bird community dynamics are strongly affected by landscape fragmentation in a Central American tropical forest region. Biodiversity and Conservation, 25: 311-330. doi: 10.1007/s10531-016-1049-2
Carpenter, J.M. and Marques, O.M. (2001). Contribuição ao Estudo dos Vespídeos do Brasil. Salvador, Universidade Federal da Bahia, Departamento de Fitotecnia. Série Publicações Digitais, v. 3, CD.

Carpenter, J. M. and Andena, S. R. (2013). The vespidae of Brazil. Manaus: Instituto nacional de Pesquisa da Amazônia, 42 p.

Clemente, M. A., Lange D., Del-Claro, K, Prezoto, F., Campos N. R. and Barbosa B. C. (2012). Flower-visiting social wasps and plants interaction: network pattern and environmental complexity. Psyche: 1-10. doi: 10.1155/2012/478431

Costa, R.B. (2003). Fragmentação florestal e alternativas de desenvolvimento rural na região Centro-Oeste. Campo Grande: UCDB, 246 p.

Cruz, J. D., Giannotti, E., Santos, G. M. M., Bichara filho, C. C. and da Rocha, A. A.( 2006). Nest Site Selection and Flying Capacity of Neotropical Wasp Angiopolybia pallens 
(Hymenoptera: Vespidae) in the Atlantic Rain Forest, Bahia State, Brazil. Sociobiology, 47(3): 739-749.

Dean, W. (1997). A ferro e fogo: a história e a devastação da Mata Atlântica brasileira. São Paulo: Companhia das Letras, $484 \mathrm{p}$.

Devictor, V., Julliard, R. and Jiguet, F. (2008). Distribution of specialist and generalist species along spatial gradients of habitat disturbance and fragmentation. Oikos, 117: 507-514. doi: 10.1111/j.0030-1299.2008.16215.x

Francisco, G. S., Souza, M. M., Clemente, M. A. and Brunismann, Â. G. (2018). Substrato vegetal utilizado para nidificação de vespas sociais (Hymenoptera, Vespidae) em Floresta Decidual. Revista Agrogeoambiental, 10(3): 35-45. doi: 10.18406/2316$1817 \mathrm{v} 10 \mathrm{n} 320181162$.

Fox, B.J. and Fox, M.D. (2000). Factors determining mammal species richness on habitat islands and isolates: habitat diversity, disturbance, species interactions and guild assembly rules. Global Ecol. Biogeogr., 9: 19-37. doi: 10.1046/j.13652699.2000.00184.x

Gaston, K. J. (2010). Valuing common species. Science, 327: 154-155. doi: 10.1126/science. 1182818

Gomes, L., Gomes, G., Oliveira, H.G., Junior, J.J.M., Desuó, I.C., Silva, I.M., Shima, S.N. and Zuben, C.J.V. (2007). Foraging by Polybia (Trichothorax) ignobilis (Hymenoptera, Vespidae) on flies at animal carcasses. Revista Brasileira de Entomologia, 51: 389-393. doi: 10.1590/S0085-5626200700 0300018

Graça, M. B. and Somavilla, A. (2018). Effects of forest fragmentation on community patterns of social wasps (Hymenoptera: Vespidae) in Central Amazon. Austral Entomology. doi: 10.1111/aen.12380

Hunt, J.H., o'Donnell, S., Chernoff, N. and Brownie, C. (2001). Observations on two neotropical swarn-founding wasps Agelaia yepocapa and Agelaia panamaensis (Hymenoptera: Vespidae). Annals of the Entomological Society of America, 94: 555-562. doi: 10.1603/0013-8746(2001)094[0555:OOTNSF]2.0.CO;2

Hunt, J.H. (2007). The evolution of social wasps. Oxford University

Krebs, C.J. (1998). Ecological methodology. New York: Addison Wesley Longman, $620 \mathrm{p}$.

Laurance, W.F., Nascimento, H., Laurance, S.G., Andrade, A., Fearnside, P.M. and Ribeiro, J., (2006). Rain forest fragmentation and the proliferation of successional trees. Ecology, 87: 469-482. doi: 10.1890/05-0064

Lovejoy, T.E., Bierregaard, R.O., Rylands, A., Malcolm, J., Quintela, C., Harper, L., Brown, K., Powell, A., Powell, G., Schubart, H. and Hays, M. (1986). Edge and other effects of isolation on Amazon forest fragments. In: Soule', M.E. (Ed.), Conservation Biology: The Science of Scarcity and Diversity.
Sinauer, Sunderland, Massachusetts: 257-285.

Matthews, T.J., Cottee-Jones, H.E. and Whittaker, R.J. (2014). Habitat fragmentation and the species-area relationship: a focus on total species richness obscures the impact of habitat loss on habitat specialists. Diversity and Distributions, 20: 1136-1146. doi: 10.1111/ddi.12227

Morato, E.F., and Campos, L.A.D.O. (2000). Effects of forest fragmentation on solitary wasps and bees in an area in Central Amazônia. Revista Brasileira de Zoologia, 17(2): 429-444. doi: 10.1590/S0101-81752000000200014

Myers, N., R. A., Mittermeier, C. G., Mittermeier, G. A. B., Da Fonseca, and J. Kent. (2000). Biodiversity hotspots for conservation priorities. Nature, London 403: 853-845. doi: $10.1038 / 35002501$

Nascimento, H., Andrade, A., Camargo, J., Laurance, W.F., Laurance, S.G. and Ribeiro, J. (2006). Effects of the surrounding matrix on tree recruitment in Amazonian forest fragments. Conserv. Biol., 20: 853-860. doi: 10.1111/j.15231739.2006.00344.x

Nordén, J., Penttilä, R., Siitonen, J., Tomppo, E. and Ovaskainen, O. (2013). Specialist species of wood-inhabiting fungi struggle while generalists thrive in the fragmented boreal forests. Journal of Ecology, 101: 701-712. doi: 10.1111/13652745.12085

Oliveira-Filho, A. T. (2006). Definição e delimitação de domínios e subdomínios das paisagens naturais do Estado de Minas Gerais. In: Scolforo, J. R. and Carvalho, L. M. T. (Ed.) Mapeamento e inventário de Flora e dos Reflorestamentos de Minas Gerais. Lavras: UFLA, cap. 1, 21-35.

Prezoto, F., Lima, M.A.P. and Machado, V.L.L. (2005). Survey of preys captured and used by Polybia platycephala (Richards) (Hymenoptera: Vespidae: Epiponini). Neotropical Entomology, 34: 849-851. doi: 10.1590/S1519-566X2005000500019

Rizzini, C.T. (1997).Tratado de Fitogeografia do Brasil: aspectos ecológicos, sociológicos e florísticos. Âmbito Cultural. Rio de Janeiro: Edições Ltda, 747p.

Santos, G. M. M., Aguiar, C. M. L. and Gobbi, N. (2006). Characterization of the social wasp guild (Hymenoptera, Vespidae) visiting flowers in the Caatinga (Itatim, Bahia, Brazil). Sociobiology, 47: 1-12.

Santos, G. M. M., Bichara Filho, C. C., Resende, J. J., Cruz, J. D. and Marques, O. M. (2007). Diversity and community structure of social wasps (Hymenoptera, Vespidae) in three ecosystems in Itaparica Island, Bahia State, Brazil. Neotropical Entomology, 36: 180-185. doi: 10.1590/S1519566X2007000200002

Santos, G.M.M., Cruz, J.D., Marques, O.M. and Gobbi, N. (2009). Diversidade de vespas Sociais (Hymenoptera: Vespidae) em áreas de cerrado na Bahia. Neotropical Entomology, 38: 317-320. 
Schwartz-filho, D.L., Laroca, S. and Malkowski, S.R. (2004). Livro vermelho da fauna ameaçada no Paraná. Abelhas. http:// celepar7.pr.gov.br/livrovermelho/ acesso em 08/04/18.

Silveira, O. T. (2002). Surveying neotropical social wasps. An evaluation of methods in the "Ferreira Penna" Research Station (ECFPn), in Caxiuana, PA, Brazil (Hymenoptera., Vespidae, Polistinae). Papéis Avulsos de Zoologia, 42: 299-323. doi: 10.1590/S0031-10492002001200001

Souza, M. M. and Prezoto, F. (2006). Diversity of social wasps (Hymenoptera, Vespidae) in Semideciduous forest and cerrado (savanna) regions in Brazil. Sociobiology, 4: 135-147.

Souza, M. M., Louzada, J., Serrão, J. E. and Zanuncio, J. C. (2010). Social wasps (Hymenoptra: Vespidae) as indicators of conservation degree of riparian forests in south east Brazil. Sociobiology, 56: 1-10.

Souza, M. M., Pires, E. P., Ferreira, M., Ladeira, T. E., Pereira, M., Elpino-Campos, A. and Zanuncio, J. C. (2012). Biodiversidade de vespas sociais (Hymenoptera: Vespidae) do Parque Estadual do Rio Doce, Minas Gerais, Brasil. MG Biota, 5: 04-19

Souza, M.M. and Zanuncio, J.C. (2012). Marimbondos-Vespas Sociais (Hymenoptera: Vespidae). Viçosa: Editora UFV, 79p.

Souza, M. M., Pires, E. P., Elpino-Campos, A. and Louzada, J. N. C. (2014). Nesting of social wasps (Hymenoptera: Vespidae) in a riparian forest of rio das Mortes in South easter in Brazil. Acta Scientiarum, 36: 189-196. doi: 10.4025/ actascibiolsci.v36i2.21460

Souza, M. M., Perillo, L.N., Barbosa, B.C. and Prezoto, F. (2015a). Use of flight interception traps of Malaise type and attractive traps for social wasps record (Vespidae: Polistinae). Sociobiology, 62: 450-456. doi: 10.13102/sociobiology.v62i3.708

Souza, M. M., Pires, E. P., Silva-Filho, R. and Ladeira, T. E. (2015b). Community of social wasps Hymenoptera: Vespidae) in areas of Semideciduous Seasonal Montane Forest. Sociobiology, 62: 598-603. doi: 10.13102/sociobiology.v62i4.445

Tischendorf, L. and Fahrig, L. (2000). On the usage and measurement of landscape connectivity. Oikos, 90: 7-19. doi: 10.1034/j.1600-0706.2000.900102.x

Tscharntke, T., Steffan-dewenter, I., Krues, A. and Thies, C. (2002). Characteristics of insect populations on habitat fragments: a mini review. Ecological Research, 17: 229-239. doi: 10.1046/j.1440-1703.2002.00482.x.

Viana, V.M. and Tabanez, A.A.J. (1996). Biology and conservation of forest fragments in the Brazilian Atlantic moist forest. In: Forest patches in tropical landscapes. Island Press: 151-167.

Viana, V. M. and Pinheiro, L. A. F. V. (1998).Conservação da biodiversidade em fragmentos florestais. Série técnica IPEF, 12: $25-42$,

Wenzel, J.W. (1991). The evolution of nest architecture in the social vespids. In: The social biology of wasps. Cornell University Press, Ithaca: 480-519.

Wenzel, J. W. and Carpenter, J. M. (1994). Comparing methods: adaptive traits and tests of adaptation. Phylogenetics and ecology, 17: 79-101.

Woodroffe, R. and Ginsberg, J.R. (1998). Edge effects and the extinction of populations inside protected areas. Science, 280: 2126-2128. DOI: 10.1126/science.280.5372.2126

Wright, S.J., Stoner, K.E., Beckman, N., Corlett, R.T., Dirzo, R., Muller-Landau, H.C., Nunez-Iturri, G., Peres, C.A. and Wang, B.C. (2007). The plight of large animals in tropical forests and the consequences for plant regeneration. Biotropica, 39: 289-291. doi: 10.1111/j.1744-7429.2007.00293.x

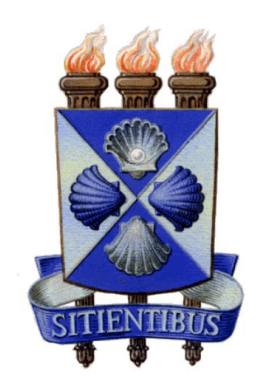

